\title{
Structural studies and antimicrobial properties of norcembrane diterpenoid from an Indian soft coral Sinularia inelegans Tixier-Durivault
}

\author{
KEISHAM SARJIT SINGH ${ }^{1, *}$, WERNER H KAMINSKY ${ }^{2}$, CELINA RODRIGUES $^{1}$ and \\ C G NAIK ${ }^{1}$ \\ ${ }^{1}$ Bioorganic Chemistry Laboratory, National Institute of Oceanography (CSIR), Goa 403004 \\ ${ }^{2}$ Department of Chemistry, University of Washington, Seattle, Washington 98195, USA \\ e-mail: keisham@nio.org; sarjitkeisham $a$ yahoo.co.in
}

MS received 15 January 2009; revised 22 May 2009; accepted 26 May 2009

\begin{abstract}
Two metabolites featuring norcembranoid diterpene skeleton have been isolated from chloroform extract of soft coral of the genus sinularia, which was collected from the southern coast of India. The structures of the metabolites were determined by 1D, 2D NMR spectroscopic data and HRESIMS data analysis. The compounds have shown moderate-to-high antimicrobial activities. The structure and the relative stereochemistry of the metabolite 1 have been determined by X-ray crystallography.
\end{abstract}

Keywords. Diterpene; sinularia; stereochemistry; antimicrobial; crystallography.

\section{Introduction}

Soft corals have been recognized as a rich source of diterpenes belonging to cembranolides, ${ }^{1-5}$ norcembranoids, ${ }^{6,7}$ and amphilactane ${ }^{8}$ classes. Among the several diterpenes reported, cembranoids and their cyclised derivatives are the most abundant metabolites of soft corals and gorgonians. ${ }^{9-14}$ They are produced as defense against prediators such as fishes, other corals and against settlement of microorganisms such as bacteria and fungi. ${ }^{15,16}$ These classes of diterpenoids are a large part of natural product compounds having variety of chemical structures. Many of these compounds were reported to possess cytotoxicity, ${ }^{17}$ anti-inflamatory ${ }^{18,19}$ and anti-microbial activities. $^{20}$

As a part of our effort to the discovery of bioactive metabolites from marine organisms, ${ }^{21}$ here, we wish to report the isolation of two norcembranoid diterpenes ( $\mathbf{1}$ and 2 ) that are epimer at one carbon atom (C-9) from the soft coral of the genus sinularia. Bioassay of the compounds against some microorganisms or clincal isolates viz. bacterium and fungus has been reported. The molecular structures of the compounds were determined by extensive NMR and ESIMS spectroscopic data analysis. The crystal

*For correspondence structure and relative stereochemistry of 1 have been established by single X-ray crystallography.

\section{Experimental}

\subsection{General experimental procedures}

Infrared spectra were obtained on a Shimadzu8201PC spectrometer with sample prepared in $\mathrm{KBr}$ and NMR spectra were recorded on a BrukerAvance $300 \mathrm{MHz}$ spectrometer at $300 \cdot 13 \mathrm{MHz}$ for ${ }^{1} \mathrm{H}$ and $75.23 \mathrm{MHz}$ for ${ }^{13} \mathrm{C}$, in $\mathrm{CDCl}_{3}$ with $\mathrm{SiMe}_{4}$ as internal reference and coupling constants are given in hertz. Proton chemical shifts were referenced to the residual $\mathrm{CHCl}_{3}$ signal $(\delta, 7 \cdot 2),{ }^{13} \mathrm{C}$ NMR spectra were referenced to the centre peak of $\mathrm{CHCl}_{3}$ signal at $\delta 77 \cdot 1$. ESIMS data were performed on QSTAR XL (LC-MS) mass spectrometer. Column chromatography were performed on silica gel (230-400 mesh, 60-120 mesh, Merck, Darmstadt, Germany or SRL, Pvt. Ltd, India) and Shephadex LH-20 and spots were visualized by spraying with $5 \% \mathrm{H}_{2} \mathrm{SO}_{4}$ solution followed by heating.

\subsection{Animal materials}

Specimens of the soft coral Sinularia inelegans Tixier-durivault were collected by hand by divers 
equipped with SCUBA off the coast of Mandapanam, Tamil Nadu, India in July, 2006 at a depth of $5-10 \mathrm{~m}$. The organism was identified by comparison with previous descriptions and a voucher specimen was deposited at the aquarium museum at the National Institute of Oceanography, Goa under Voucher No. NIO-878.

\subsection{Extraction and isolation}

Fridge dried and minced material of sinularia spicies (dry weight $180 \mathrm{~g}$, dried using Lyophilizer) was extracted step-wise with petroleum ether, Chloroform and finally with $n$-butanol. The chloroform extract was concentrated using rotary evaporator and the residue was separated by flash chromatography on a silica gel (230-400 mesh) using petroleum ether and ethyl acetate solvent system as eluant in increasing polarity (step-wise $100: 0,10: 90$, petroleum ether/ ethyl acetate and pure ethyl acetate) to yield 1-46 fractions. Fractions 38 and 39 gave a light colourless solid on evaporation at room temperature. Repeated crystallization of this solid with chloroform: petroleum ether gave a colourless rectangular crystals of compound $1(50 \mathrm{mg})$ suitable for X-ray analysis. Further separation of fraction 34 to 37 on silica gel using increasing concentration $\mathrm{MeOH}$ in $\mathrm{CHCl}_{3}$ yielded good quantity of compound $1(130 \mathrm{mg})$ and 2 (110 mg).

The spectroscopic data of the compounds are as follows:

2.3a Compound 1: FTIR $\left(\mathrm{KBr}, \mathrm{cm}^{-1}\right): v_{\max } 3586$, $3415,2943,1760,1728,1666,1406,1373,1188$, 1096. HREIMS: $m / z$ 349.0734 $[\mathrm{M}+\mathrm{H}]^{+}$(Calcd for $\left.\mathrm{C}_{19} \mathrm{H}_{25} \mathrm{O}_{6}, 349 \cdot 1651\right)$.

${ }^{1} \mathrm{HNMR}\left(\mathrm{CDCl}_{3}, \delta\right): 6.44\left(1 \mathrm{H}, d d,{ }^{3} J_{\mathrm{H}-\mathrm{H}}=4 \cdot 8\right.$, $\left.{ }^{3} J^{\prime}{ }_{\mathrm{H}-\mathrm{H}}=6.3, \mathrm{H}-19\right), 4.88(s, 1 \mathrm{H}, \mathrm{H}-16), 4.81(s, 1 \mathrm{H}$, $\mathrm{H}-16), 4.61\left(d, 1 \mathrm{H}, J_{\mathrm{H}-\mathrm{H}}=9, \mathrm{H}-4\right), 4.25(d d, 1 \mathrm{H}$, $\left.J_{\mathrm{H}-\mathrm{H}}=3, J_{\mathrm{H}-\mathrm{H}}=5 \cdot 4, \mathrm{H}-9\right), 3.70\left(d d d, 2 \mathrm{H}, J_{\mathrm{H}-\mathrm{H}}=6 \cdot 2\right.$, $\left.J_{\mathrm{H}-\mathrm{H}}=9.9, J_{\mathrm{H}-\mathrm{H}}=12.9, \mathrm{H}-18\right), 3.01(m, 1 \mathrm{H}, \mathrm{H}-14)$, $2.88\left(d, 1 \mathrm{H}, J_{\mathrm{H}-\mathrm{H}}=3, \mathrm{H}-11\right), 2.82\left(d, 1 \mathrm{H}, J_{\mathrm{H}-\mathrm{H}}=2.7\right.$, $\mathrm{H}-11), 2.64(s, 1 \mathrm{H}, \mathrm{H}-7), 2.59(s, 1 \mathrm{H}, \mathrm{H}-7), 2.50$ $\left(d, 1 \mathrm{H}, J_{\mathrm{H}-\mathrm{H}}=3 \cdot 3, \mathrm{H}-13\right), 2.47\left(d, 1 \mathrm{H}, J_{\mathrm{H}-\mathrm{H}}=2 \cdot 1\right.$, $\mathrm{H}-13), 2 \cdot 24$ (br, 1H, H-18), $2 \cdot 17$ ( $m, 2 \mathrm{H}, \mathrm{H}-5), 2 \cdot 12$ $(s, 3 \mathrm{H}, \mathrm{H}-10), 1.45(s, 3 \mathrm{H}, \mathrm{H}-17)$.

${ }^{13} \mathrm{CNMR}\left(\mathrm{CDCl}_{3}, \delta\right): 214.61$ (C-8), 205.52 (C-12), 168.55 (C-1), 147.14 (C-15), $145 \cdot 16$ (C-19), 132.36 (C-2), 110.46 (C-16), 83.26 (C-4), 79.16 (C-6), 75.06 (C-3), 74.86 (C-9), 51.33 (C-7), 46.17 (C-13), 43.19 (C-11), 42.25 (C-5), 39.69 (C-14), 28.51 (C-18), 26.51 (C-10), 21.62 (C-17). 2.3b Compound 2: IR and Mass analysis data are similar to that of 1 .

${ }^{1} \mathrm{HNMR}\left(\mathrm{CDCl}_{3}, \delta\right): 6.88\left(d d, 1 \mathrm{H}, J_{\mathrm{H}-\mathrm{H}}=5 \cdot 2\right.$, $\left.J_{\mathrm{H}-\mathrm{H}}=7.2, \mathrm{H}-19\right), 4.96(s, 1 \mathrm{H}, \mathrm{H}-16), 4.73(s, 1 \mathrm{H}$, $\mathrm{H}-16), 4.65\left(d, 1 \mathrm{H}, J_{\mathrm{H}-\mathrm{H}}=6.6, \mathrm{H}-4\right), 4.31(d d, 1 \mathrm{H}$, $\left.J_{\mathrm{H}-\mathrm{H}}=4 \cdot 2, J_{\mathrm{H}-\mathrm{H}}=6 \cdot 9, \mathrm{H}-9\right), 3.62\left(d d, 2 \mathrm{H}, J_{\mathrm{H}-\mathrm{H}}=3 \cdot 8\right.$, $\left.J_{\mathrm{H}-\mathrm{H}}=6.4, \mathrm{H}-18\right), 3.04(m, 1 \mathrm{H}, \mathrm{H}-14), 2.83(d, 1 \mathrm{H}$, $\left.J_{\mathrm{H}-\mathrm{H}}=3 \cdot 2, \mathrm{H}-11\right), 2.74(m, 1 \mathrm{H}, \mathrm{H}-11), 2.66(s, 1 \mathrm{H}$, $\mathrm{H}-7), 2.52(m, 1 \mathrm{H}, \mathrm{H}-7), 2.43\left(d, 1 \mathrm{H}, J_{\mathrm{H}-\mathrm{H}}=3\right.$, H-13) 2.27 (br, 2H-18), $2 \cdot 19$ (m, 2H, H-5), 2.14 $(m, 3 \mathrm{H}, \mathrm{H}-10), 1.49(s, 3 \mathrm{H}, \mathrm{H}-17)$.

${ }^{13} \mathrm{CNMR}\left(\mathrm{CDCl}_{3}, \delta\right): 212.86(\mathrm{C}-8), 208.29(\mathrm{C}-12)$, 170.73 (C-1), 144.70 (C-15), 142.67 (C-19), 130.90 (C-2), 112.11 (C-16), 80.26 (C-4), 77.58 (C-6), 75.78 (C-3), 75.51 (C-9), 49.43 (C-7), 48.06 (C-13), 44.45 (C-11), 41.81 (C-5), 39.69 (C-14), 29.21 (C-18), 28.70 (C-10), 21.80 (C-17).

\subsection{Antimicrobial assays}

Antimicrobial properties of the compounds were tested by employing the Kirby-Bauer's Disc diffusion technique. ${ }^{22}$ Antifungal assay was carried out against the fungus Aspergillus funigatus, Rhodotorula, Candida albicans and Aspergellus niger. The bacteria Vibrio cholerae, Escherichia coli and Staphylococcus aureus were used in the antibacterial assay. A 50-200 $\mu \mathrm{g}$ portion of the compounds were applied onto pre-sterilised disc. The disc was placed on agar plates that had been seeded with respective organisms. Diameters of inhibitory zones were measured after the plates were incubated at $28^{\circ} \mathrm{C}$ for 24-48 h. Nystatin and Penicillium were used as positive control for fungus and bacteria, respectively.

\subsection{Crystallographic data analysis}

Crystals of suitable for X-ray analysis were grown from chloroform and petroleum ether. X-ray structural data were measured at $130(2)^{\circ} \mathrm{K}$ on a NoniusKappa CCD diffractometer using $\mathrm{M}_{0}-\mathrm{K} \alpha$ radiation $(\lambda=0.71073 \AA)$. A crystal of suitable size was mounted using epoxy or paraffin and the diffraction data were then collected. Data collection and cell refinement involved HKL-SCALEPACK ${ }^{23}$ software packages. Molecular graphic was done using $\mathrm{maXus^{24 }}$ and zortep ${ }^{25}$ softwares. The structure was solved by direct methods ${ }^{26}$ and refined by full matrix least squares base on $F^{2} \cdot{ }^{27}$ Weighting scheme calculated used was $w=1 /\left[s^{2}\left(F O^{2}\right)+(0 \cdot 0672 P)^{2}+0 \cdot 0000 P\right]$, 
Table 1. Selected bond lengths $(\AA)$ and angles $\left(^{\circ}\right)$ for the metabolite $\mathbf{1 .}$

\begin{tabular}{|c|c|c|c|}
\hline \multicolumn{4}{|l|}{ Bond lengths $(\AA)$} \\
\hline $\mathrm{C} 15-\mathrm{C} 16$ & $1 \cdot 323(4)$ & C14-C18 & $1 \cdot 557(3)$ \\
\hline C5-C6 & $1.526(4)$ & C9-H9 & 1.000 \\
\hline $\mathrm{C} 1-\mathrm{O} 3$ & $1 \cdot 208(3)$ & C15-C16 & $1 \cdot 323(4)$ \\
\hline $\mathrm{C} 3-\mathrm{O} 2$ & $1.462(3)$ & C18-C19 & $1 \cdot 504(4)$ \\
\hline $\mathrm{C} 1-\mathrm{O} 1$ & $1 \cdot 354(3)$ & $\mathrm{C} 14-\mathrm{C} 15$ & $1 \cdot 520(3)$ \\
\hline C8-O6 & $1 \cdot 218(3)$ & $\mathrm{O} 2-\mathrm{H} 2$ & $0 \cdot 8400$ \\
\hline \multicolumn{4}{|l|}{ Bond angles $\left(^{\circ}\right)$} \\
\hline C13-C14-C18 & $112 \cdot 5(2)$ & $\mathrm{C} 4-\mathrm{O} 1-\mathrm{C} 1$ & $112.08(19)$ \\
\hline C9-O4-C6 & $108 \cdot 88(18)$ & $\mathrm{C} 4-\mathrm{C} 3-\mathrm{C} 2$ & $104 \cdot 2(2)$ \\
\hline $\mathrm{C} 7-\mathrm{C} 8-\mathrm{C} 9$ & $107 \cdot 7(2)$ & C16-C15-C17 & $121 \cdot 9(2)$ \\
\hline $\mathrm{C} 3-\mathrm{O} 2-\mathrm{H} 2$ & $109 \cdot 5$ & $\mathrm{O} 1-\mathrm{C} 1-\mathrm{C} 2$ & $109.7(2)$ \\
\hline $\mathrm{O} 3-\mathrm{C} 1-\mathrm{O} 1$ & $120 \cdot 0(2)$ & $\mathrm{O} 3-\mathrm{C} 1-\mathrm{C} 2$ & $130 \cdot 2(2)$ \\
\hline
\end{tabular}

Table 2. Summary of crystal structure determination and refinement of compound $\mathbf{1 .}$

\begin{tabular}{|c|c|}
\hline Empirical formula & $\mathrm{C}_{19} \mathrm{H}_{24} \mathrm{O}_{6}$ \\
\hline Formula weight & $348 \cdot 38$ \\
\hline Temperature & $130(2) \mathrm{K}$ \\
\hline Wavelength & $0.71073 \AA$ \\
\hline Crystal description & Prism \\
\hline Colour & Colourless \\
\hline Crystal system & Monoclinic \\
\hline Space group & $P_{21}$ \\
\hline Unit cell dimensions & $\begin{array}{l}a=11 \cdot 5091(4) \AA \alpha=90^{\circ} \\
b=6 \cdot 0530(2) \AA \beta=98.6837(14)^{\circ} \\
c=12 \cdot 5303(7) \AA \gamma=90^{\circ}\end{array}$ \\
\hline Volume & $862 \cdot 91(6) \AA^{3}$ \\
\hline$Z$ & 2 \\
\hline Calculated density & $1 \cdot 341 \mathrm{Mg} / \mathrm{m}^{3}$ \\
\hline Absorption coefficient & $0.099 \mathrm{~mm}^{-1}$ \\
\hline$F(000)$ & 372 \\
\hline Crystal size & $0.59 \times 0.48 \times 0.30 \mathrm{~mm}$ \\
\hline Reflections for indexing & 534 \\
\hline Theta range for data collection & $2 \cdot 24$ to $28 \cdot 31^{\circ}$ \\
\hline Index ranges & $\begin{array}{l}-15 \leq h \leq 14 \\
-6 \leq k \leq 8 \\
-16 \leq 1 \leq 16\end{array}$ \\
\hline Reflections collected/unique & $3787 / 2256[R($ int $)=0 \cdot 0406]$ \\
\hline Completeness to $\theta$ & $25.00-99.8 \%$ \\
\hline Absorption correction & Semi-empirical from equivalents \\
\hline Maximum and minimum transmission & 0.9608 and 0.9537 \\
\hline Refinement method & Full-matrix least-squares on $F^{2}$ \\
\hline Data/restraints/parameters & $2256 / 1 / 229$ \\
\hline Goodness-of-fit on $F^{2}$ & $0 \cdot 988$ \\
\hline Final $R$ indices & $R_{1}=0.0438$ \\
\hline$[I>2 \sigma(I)]$ & $w R_{2}=0.1012$ \\
\hline$R$ indices (all data) & $R_{1}=0.0620, w R_{2}=0.1086$ \\
\hline Largest diff. peak and hole & 0.202 and $-0.221 \mathrm{eA}^{-3}$ \\
\hline
\end{tabular}

where $P=\left(F O^{2}+2 F c^{2}\right) / 3$. Non hydrogen atoms were refined anisotropically and all hydrogen atoms were initially located in a difference Fourier map and were refined with a 'riding' model. Refinement converged at a final $R_{1}=0.0438$ and $w R_{2}=0.1012$. Selected bond lengths and angles are presented in table 1. Summary of data collection parameters and refinement data are given in table 2 . 


\section{Crystal structure}

Crystals of compound 1 were obtained from chloroform and petroleum ether solvent system and crystallize in $P_{21}$ space group in a monoclinic unit cell. The molecular structure of compound 1 with atoms labelling scheme is shown in figure 1. The structure consists of three cyclic chains, one five-member lactone, one five member ethereal ring and a thirteenmembered ring. In consistent with NMR data the structure showed the presence of a double bond between $\mathrm{C} 2$ and $\mathrm{C} 19$ (1.335(4)) $\AA$, which is within the usual range of $\mathrm{C}=\mathrm{C}$ bond. All the three carbonyl bond lengths, C1-O3 (1.208), C8-O6 (1.218) and C12-O5 (1.218) $\AA$ are comparable and the values are within the reported range of $\mathrm{C}-\mathrm{O}$ bond length. ${ }^{28}$

\section{Results and discussion}

Chemical investigation of chloroform extract of soft coral of genus sinularia collected from the southern part of India leads to isolation of two known metabolites (1 and 2 ) featuring norcembranoids diterpene skeleton along with a few other metabolites, investigation of which is under progress. The norcembranoid 1 was C-9 epimer of 2 and the relative steriochemistry of $\mathbf{1}$ was established by X-ray crystallography and assigned the chiral centres as ( $3 \mathrm{~S}^{*}, 4 \mathrm{R}^{*}, 6 \mathrm{~S}^{*}, 9 \mathrm{R}^{*}, 14 \mathrm{~S}^{*}$ ). The compound 1 and 2 have been isolated from chloroform fraction with the help of chromatographic technique. The ${ }^{1} \mathrm{H}$ and ${ }^{13} \mathrm{C}$ NMR spectrum of $\mathbf{2}$ is similar to that of $\mathbf{1}$ and initially they are difficult to distinguish by the NMR spectral data. However, a careful observation of their

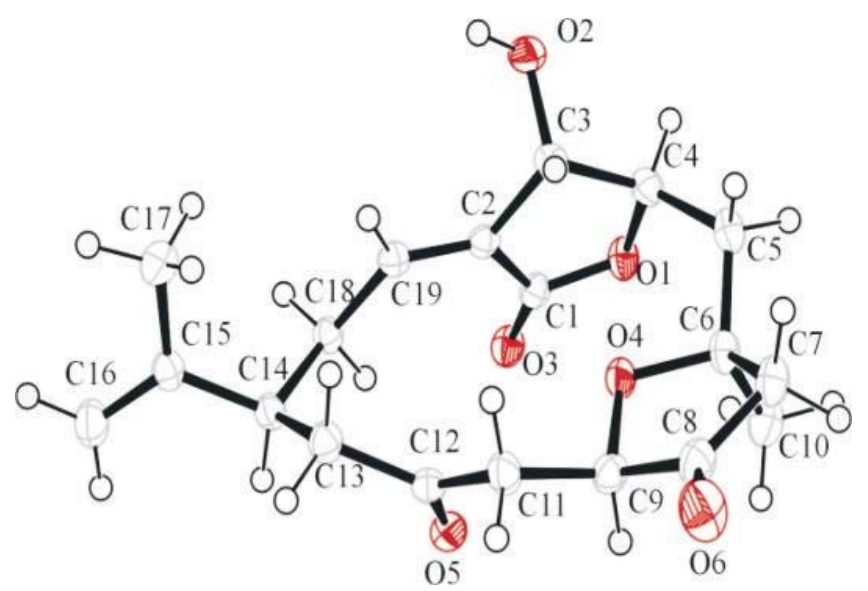

Figure 1. Molecular structure of compound 1 with atoms numbering scheme.
${ }^{13} \mathrm{C}$ NMR spectrum reveals that there is slight difference on their ${ }^{13} \mathrm{C}$ chemical shift values suggesting that $\mathbf{2}$ is stereoisomer of $\mathbf{1}$. Compound $\mathbf{1}$ was easily separated from the mixture as colourless crystals on crystallization in chloroform and petroleum ether or more conveniently using chloroform and ethyl acetate. While 2 was isolated from the mixture as light yellow compound upon repeated chromatography over silica gel followed by crystallization. It is noteworthy that $\mathbf{1}$ and $\mathbf{2}$ are isolated as a mixture by chromatography but on crystallization 1 can be readily isolated from 2 . The molecular formula of the compound 1 was found to be $\mathrm{C}_{19} \mathrm{H}_{24} \mathrm{O}_{6}$ as determined by ESIMS $\left(\mathrm{m} / z\right.$ 349.0734 $[\mathrm{M}+\mathrm{H}]^{+}$calculated for $\mathrm{C}_{19} \mathrm{H}_{25} \mathrm{O}_{6}, 349 \cdot 1651$ ). The presence of hydroxyl group was supported by the appearance of a broad absorption peak in the IR spectrum at $3452 \mathrm{~cm}^{-1}$. The IR spectrum of compound 1 and 2 showed strong bands at $1760,1728 \mathrm{~cm}^{-1}$ consistent with the presence of lactone and carbonyl group. ${ }^{29}$ The Proton NMR spectra of 1 and $\mathbf{2}$ showed the presence of oxy-methylene proton (see experimental section). The ${ }^{13} \mathrm{C}$ NMR of the compounds displayed nineteen distinct carbon signals which were assigned by the assistance of DEPT as two methyls, six methylene, five methines including three oxygenated and one vinylic $\left(\delta_{\mathrm{C}} 39.69,145 \cdot 16,75 \cdot 06,83 \cdot 26,74 \cdot 86\right)$, three quaternary carbons $(147 \cdot 14,132 \cdot 36,79.16)$ and three carbonyl carbons. The carbon signals appearing at $\delta$ $214.6,168.5$ and 147.1 could be attributed to the presence of normal ketone and $\alpha, \beta$ conjugated ester in the compound 1 . The presence of hydroxyl group in compounds was recognised from ${ }^{13} \mathrm{C}$ NMR resonance at $\delta_{\mathrm{C}} 75.06$ for 1 and 75.78 for 2 . Further MS/MS of the compound 1 gave peak at $\mathrm{m} / \mathrm{z}$ 331.1096 (ESIMS, $m / z$ 331.1096 [M- $\left.\mathrm{H}_{2} \mathrm{O}\right]^{+}$) corresponding to the losts of a water molecule indicating the presence of hydroxyl group in the molecule.

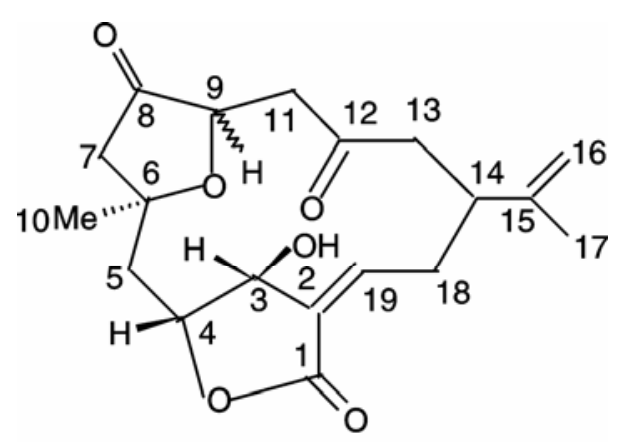

$1(9 R) 2(9 s)$ 
The presence of terminal alkene in $\mathbf{1}$ or $\mathbf{2}$ was supported by the appearance of singlet at $4.79 \mathrm{ppm}$ in the proton NMR spectrum and is further confirmed by the following reaction. ${ }^{28}$ Treatment of 1 or 2 with sodium in dry methanol resulted in hydrogenation at $\mathrm{C}-15$ to give a methoxy derivative 3 . The formation of methoxy derivative $\mathbf{3}$ was confirmed by the absence of terminal olifenic proton signal at around $\delta 4.81$ observed in 1 and appearance of a broad signal at $\delta 3.82$ assignable to the proton of methoxy group. This observation leads to the conclusion that metabolite $\mathbf{1}$ contains a terminal alkene group and proposed the structure of the metabolite as 1 .

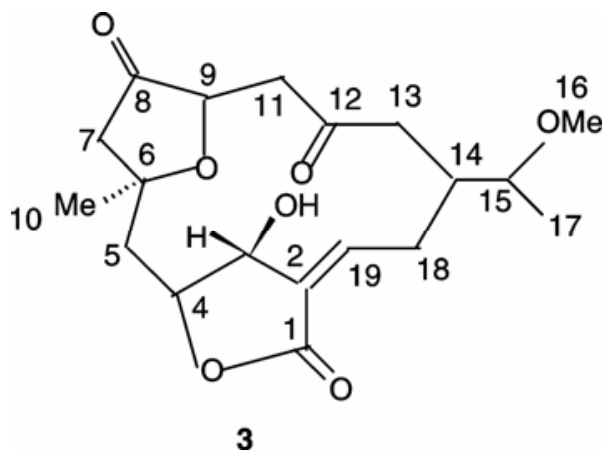

The solid state structure of $\mathbf{1}$ has been finally confirmed by crystallographic study. The metabolites 1 and $\mathbf{2}$ have been reported by earlier workers isolated from sinularia leptoclados ${ }^{30}$ and other sinularia species. ${ }^{31}$ The spectroscopic data of $\mathbf{1}$ and $\mathbf{2}$ are well matched with the reported values. In this communication, we described the stereochemistry and antimicrobial properties of the metabolites.

Compounds were tested for antimicrobial activities against sixteen clinical isolates by following a procedure described previously. ${ }^{22}$ Bioassay studies of the compounds shown a moderate-to-high activities against certain pathogens such as Vibrio cholerae, Aspergillus funigatus, Escherichia coli and Staphylococcus aureus.

\section{Conclusions}

Two metabolites featuring norcembranoid diterpenes with antimicrobial properties have been isolated and fully characterized on the basis of FTIR, NMR $\left({ }^{1} \mathrm{H}\right.$, ${ }^{13} \mathrm{C}$, DEPT) and ESIMS data. The relative stereochemistry of the compound 1 was established with the help of X-ray analysis.

\section{Acknowledgements}

K S S gratefully acknowledges the financial support from the Council of Scientific and Industrial Research (CSIR), India. We thank the reviewers for helpful suggestions.

\section{Supplementary material}

Crystallographic data for the structural analysis have been deposited at the Cambridge Crystallographic Data Centre (CCDC), with CCDC No. 673651 for 1. Copies of this information may be obtained free of charge from the Director, CCDC, 12 Union Road, Cambridge, CB2 1EZ, UK (fax: +44-1223-336033; e-mail: deposit@ccdc.cam.ac.uk or http://www. ccdc.cam.ac.uk).

\section{References}

1. Gokdshlager GK, Klein P, Rudi A, Banyahu Y, Schleyer M and Kashman Y 1996 J. Nat. Prod. 59 262

2. Bowden B F, Coll J C, Mitchell S J and Kazlauskas R 1981 Aust. J. Chem. 341551

3. Li G, Zhang Y, Deng Z, Olwegnen Z, Proksch P and Lin W 2005 J. Nat. Prod. 68649

4. Radhika P, Rao P R, Archana J and Rao N K 2005 Biol. Pharm. Bull. 281311

5. Zhang C X, Yan S J, Zheng G W, Lu W G, Su J Y and Zeng L M 2005 J. Nat. Prod. 651087

6. Rudi A, Shmul G, Banyahu Y and Kashman Y 2006 Tetrahedron Lett. 472937

7. Tseng Y J, Ahmed A F, Dai CF, Chiang MY and Shen J H 2005 Org. Lett. 73813

8. Yamada K, Ujiie T, Yoshida K, Miyamoto $\mathrm{T}$ and Highuchi R 1997 Tetrahedron $\mathbf{5 3} 4569$

9. Faukner D J 1999 Nat. Prod. Rep. 16155

10. Faukner D J 2000 Nat. Prod. Rep. 177

11. Faukner D J 2001 Nat. Prod. Rep. 181

12. Faukner D J 2002 Nat. Prod. Rep. 191

13. Krebs H C 1986 Prog. Chem. Org. Nat. Prod. 49208

14. Tursch B, Braekman J C, Daloze D and Kaisin M 1978 In Marine natural product (ed.) P J Scheuer (New York: Academic Press) vol. 2, p. 247

15. Coll J C, Price I R, Koenig G M and Bowden B F 1987 Mar. Biol. 96129

16. Coll J C, Bowden B F, Alino P M, Heaton A, Koenig G M, Nys, R, Willis R H, Sammarco P W and Clayton M N 1989 Chem. Scr. 29383

17. Yamada $\mathrm{K}$, Ujiie $\mathrm{T}$, Yoshida $\mathrm{K}$, Miyamoto $\mathrm{T}$ and Highuchi R 1997 Tetrahedron 534569

18. Buckle P J, Baldo B A and Tylor K M 1980 Agents Actions 10361

19. Takaki H, Koganemaru R, Iwakawa Y, Higuchi R and Miyamato T 2003 Biol. Pharm. Bull. 26380 
20. Aceret T L, Coll J C, Uchio Y and Sammaraco P W 1998 Comp. Biochem. Physiol. C121 121

21. Tilvi S, Rodrigues C, Naik C G, Parameswaran P S and Wahidhulla S 2004 Tetrahedron 6010207

22. Bauer A W, Kirby W M, Sherris J C and Truck M 1966 Am. J. Clin. Pathol. 45493

23. Otinowski $Z$ and Minor W 1996 In Processing of X-ray diffraction data collected in oscillation mode. Methods in enzymology (eds) C W Carter Jr and R M Sweet (Academic Press) vol. 276, p. 307

24. MacKay S, Gilmore C J, Edwards C, Tremayne M, Stewart N and Shankland K 1998 maXus: A computer program for the solution and refinement of crystal structures from diffraction data (eds) U K Scotland and B V Nonius Delft, University of Glasgow (Yokohama, Japan: The Netherlands and MacScience Co. Ltd.)
25. Zortep: Zsolnai L and Huttner G 1994 (University of Heidelberg)

26. SIR97: Altomare A, Cascarano G, Giacovazzo C, Burla M C, Polidori G and Camalli M 1994 J. Appl. Cryst. 27 435

27. Sheldrick G M 1997 SHELXL97: Program for the Refinement of Crystal Structures (Germany: University of Gottingen)

28. Uchio Y, Eguchi S, Kuramoto J, Nakayama M and Hase T 1985 Tetrahedron Lett. 264487

29. Iwashima M, Matsumoto Y, Takenaka Y, Iguchi $\mathrm{K}$ and Yamori I 2002 J. Nat. Prod. 651441

30. Ahmed A F, Shiue R T, Wang G H, Dai C F, Kua Y H and Sheu J H 2003 Tetrahedron 597337

31. Noboru S, Umeyama K and Arihara S 1993 J. Nat. Prod. 561651 